\title{
The Importance of Free Bilirubin Acid Salt in Bilirubin Uptake by Erythrocytes and Mitochondria
}

\author{
RICHARD P. WENNBERG \\ Division of Neonatology, Department of Pediatrics, School of Medicine, University of California,
} Davis, California 95616

\begin{abstract}
The binding of bilirubin to tissue was studied using adult human erythrocytes and rat liver mitochondria. Tissues were incubated with varying bilirubin-albumin molar ratios, varying albumin concentrations of a given bilirubin-albumin molar ratio, and varying $\mathrm{pH}$. Bilirubin binding by tissue was reversible and stoichiometric with the concentration of the free (nonalbumin bound) bilirubin acid salt (bilirubin monovalent anion). Minimal binding of the bilirubin dianion, the predominant state of bilirubin in plasma, was also suggested. The observations support the "free bilirubin theory" where tissue and albumin compete for binding the body's bilirubin pool. Binding to tissue, however, is not determined by the free bilirubin concentration, but by the concentration of the $\mathrm{pH}$ dependent subfraction, the free bilirubin acid salt. Tissue binding and toxicity of bilirubin may result from the surfactant properties of the monovalent anion. (Pediatr Res 23: 443-447, 1988)
\end{abstract}

\section{Abbreviations}

$\mathrm{BH}_{2}$, bilirubin acid

$\mathrm{BH}^{-}$, bilirubin acid salt (monovalent bilirubin acid)

$\mathbf{B}^{=}$, bilirubin dianion

HSA, human serum albumin

HEPES, $\quad N$-2-hydroxyethylpiperazine- $N^{\prime}$-2-ethanesulfonic acid

The "free bilirubin theory" of kernicterus assumes that tissue and albumin are competing with each other for binding the body's bilirubin pool $(1,2)$, where

"free" bilirubin + albumin $\rightarrow$ bilirubin-albumin

and

$$
\text { "free" bilirubin }+ \text { cell } \rightarrow \text { bilirubin-cell }
$$

When equilibrium is achieved the free (unbound) bilirubin concentration in reactions 1 ) and 2) will be identical so that,

bilirubin-albumin $\rightarrow$ albumin + free bilirubin

$$
+ \text { cell } \longrightarrow \text { bilirubin-cell }
$$

The concentration of bilirubin in tissue can then be estimated by measuring the free bilirubin concentration in serum. The validity of reaction 1) is well supported; there is substantial evidence that albumin binds bilirubin reversibly in plasma even

Received October 6, 1987; accepted December 17, 1987.

Correspondence Richard P. Wennberg, M.D., Division of Neonatology-TB 193 University of California, Davis, CA 95616.

Supported in part by grants from the United Cerebral Palsy Association and the United States Public Health Service HD10491. though only a very small fraction of the total bilirubin remains unbound $(2,3)$. Direct evidence to support reaction 2) is not conclusive. Phospholipids and cell membranes bind bilirubin (48 ), but less is known about the stoichiometry or reversibility of tissue binding. Some $(9,10)$ have suggested that tissue uptake of bilirubin is mediated by its albumin carrier and not dependent on free bilirubin at all. The recognition that $\mathrm{pH}$ affects each of these reactions differently further complicates this model. Within the physiologic $\mathrm{pH}$ range, bilirubin binding to albumin is essentially independent of hydrogen ion concentration $(11,12)$, but bilirubin binding to tissue increases at lower $\mathrm{pH}(8,12-14)$. Inasmuch as $\mathrm{pH}$ influences binding to a variety of cell membranes, mitochondria, phospholipid liposomes, and even sephadex (15), the explanation for the effect is more likely to be found in the chemistry of bilirubin than in $\mathrm{pH}$-induced alterations of the membranes.

Bilirubin is a dicarboxylic acid, with three species in equilibrium:

$$
\mathrm{B}=\stackrel{H^{+}}{\rightleftharpoons} \mathrm{BH}^{-} \stackrel{H^{+}}{\rightleftharpoons} \mathrm{BH}_{2} \rightarrow\left(\mathrm{BH}_{2}\right)_{\mathrm{n}} \text { (precipitate) }
$$

At physiologic $\mathrm{pH}$, most bilirubin is thought to exist as $\mathrm{B}^{\mathbf{x}}$ with a small fraction forming the acid salt (monovalent anion, $\mathrm{BH}^{-}$) and a minute fraction as $\mathrm{BH}_{2}(3)$. Because the $\mathrm{BH}_{2}$ is nearly insoluble in water, Brodersen and coworkers $(6,7,16)$ suggested that free bilirubin exists in a supersaturated metastable state under conditions of hyperbilirubinemia, and that the increased tissue uptake of bilirubin at low $\mathrm{pH}$ results from the aggregation of the insoluble bilirubin acid in membranes. Such precipitates would be irreversibly bound to tissue until the surrounding free bilirubin concentration drops below the level of bilirubin solubility. This hypothesis limits the "free bilirubin theory" inasmuch as the theory assumes that tissue binding is reversible and stoichiometrically related to the free bilirubin concentration. In view of these uncertainties, this study was undertaken to examine the validity of the bilirubin-cell reaction, namely; 1) the role of free (nonalbumin bound) bilirubin in tissue uptake in vitro, 2) the stoichiometry and reversibility of bilirubin binding to tissue, and 3 ) the influence of $\mathrm{pH}$ on cell uptake of bilirubin and its implications.

\section{MATERIALS AND METHODS}

Bilirubin, defatted HSA, fraction $\mathrm{V}$, and horseradish peroxidase (EC 1.11.1.7) were obtained from Sigma Chemical Co. Ethyl hydrogen peroxide was obtained from Accurate Chemical Company. Bilirubin was dissolved in $0.1 \mathrm{~N} \mathrm{NaOH}$ and added to an unbuffered solution of HSA. The bilirubin-albumin solution was then buffered with an equal volume of $0.11 \mathrm{M}$ sodium phosphate buffer of the desired $\mathrm{pH}$ (final phosphate concentration $0.055 \mathrm{M}$ ). In most instances the final albumin concentration was $1 \mathrm{~g} / \mathrm{dl}(152 \mu \mathrm{M})$ with variable bilirubin levels. 
Erythrocyte suspensions were prepared from heparinized blood obtained from healthy adult volunteers. Approximately 50 $\mathrm{ml}$ whole blood was centrifuged for $10 \mathrm{~min}$ at $10,000 \mathrm{rpm}$ at $4^{\circ}$ C. Plasma was removed and cells were resuspended in phosphate

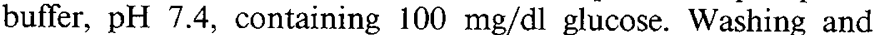
centrifugation was performed three times, and packed cells were then resuspended in an equal volume of buffer. In most uptake experiments, $1.0 \mathrm{ml}$ erythrocyte suspension was incubated with $9.0 \mathrm{ml}$ bilirubin-albumin buffer solutions in a shaking water bath, $37^{\circ} \mathrm{C}$, for $15 \mathrm{~min}$. Preliminary studies indicated that $95-$ $98 \%$ recoverable bilirubin was bound to erythrocytes by 5 min incubation. Prolonged incubation for $1 \mathrm{~h}$ increased uptake only slightly. After incubation, cells were centrifuged and the supernatant removed for total and free bilirubin determinations. After

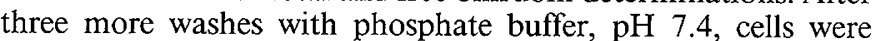
resuspended in $5 \mathrm{ml}$ of a $2 \mathrm{~g} / \mathrm{dl}$ albumin solution (phosphate buffer $\mathrm{pH}$ 7.4) and reincubated for $15 \mathrm{~min}$. The cells were again centrifuged and the supernatant saved for bilirubin determination. A total of $89-96 \%$ of the initial bilirubin could be accounted for by combining the residual serum bilirubin concentration and cell extraction. A second incubation of erythrocytes with albumin increased extraction only $1-3 \%$.

Bilirubin concentrations in supernatants were determined spectrophotometrically, assuming a molar extinction of 47,500 at $460 \mathrm{~nm}$. Hemolysis in incubation and extraction solutions was negligible. Unbound bilirubin concentrations were determined using the peroxidase method (17). Resuspended erythrocytes were counted in triplicate using a counting chamber. Bilirubin uptake is expressed as nmol $/ 10^{10}$ erythrocytes.

Mode of bilirubin uptake by erythrocytes. Because of the high binding constant of the bilirubin-albumin complex $(\mathrm{K}=4.5 \times$ $10^{7} \mathrm{M}^{-1}$ at $37^{\circ} \mathrm{C}$ ), a 10 -fold dilution of concentrated bilirubinalbumin solution has a negligible effect on the free bilirubin concentration, whereas albumin and total bilirubin levels are reduced to one-tenth the initial concentration. Thus serum dilution can be used to discriminate the action of free bilirubin from total bilirubin or albumin. Bilirubin-albumin solutions containing $2 \mathrm{~g} / \mathrm{dl}$ albumin and 9 or $14 \mathrm{mg} / \mathrm{dl}$ bilirubin (molar ratios $0.5,0.8$ ) were prepared in phosphate buffer, $\mathrm{pH}$ 7.4. The bilirubin-albumin solutions were then diluted 1:10 with buffer. Two-ml aliquots of packed washed erythrocytes were incubated with $30 \mathrm{ml}$ of diluted and undiluted bilirubin solutions for 20 min at $37^{\circ} \mathrm{C}$ after which red cells were washed and bilirubin extracted. Results are reported as the mean value of triplicate incubations performed under each set of conditions.

Stoichiometry and reversibility of bilirubin-tissue complexes. Erythrocytes $(1.0 \mathrm{ml})$ were incubated with bilirubin/albumin ratios ranging $0.2-1.3(9.0 \mathrm{ml})$. The initial albumin concentration was $1 \mathrm{~g} / \mathrm{dl}$ with variable bilirubin concentrations. Unbound bilirubin levels and red cell bilirubin content were determined after a 15-min incubation. In a second set of experiments to study reversibility of binding, erythrocytes were preloaded with bilirubin by incubation with a 1.3 molar ratio bilirubin/albumin. The postincubation molar ratio and free bilirubin concentration were about 1.05 and $76 \mathrm{nmol} /$ liter, respectively. Preloaded cells were then washed and incubated with varying molar ratios $(0.2-$ 0.9 ) as described above.

Effects of $p H$ on bilirubin binding. These studies were conducted using $1.0 \mathrm{ml}$ erythrocytes, $9.0 \mathrm{ml}$ bilirubin/albumin (molar ratio ca. 0.7). The $\mathrm{pH}$ of the $0.055 \mathrm{M}$ phosphate buffer varied from 6.9 to 7.7. To be certain that hydrogen ion effects on tissue binding were not unique to erythrocytes, similar experiments were performed with rat liver mitochondria. Mitochondria were isolated using standard differential centrifugation techniques (18) and suspended in HEPES buffer adjusted to $\mathrm{pH} 7.0-7.7$. One $\mathrm{ml}$ mitochondria suspension was added to $9.0 \mathrm{ml}$ HEPES buffered bilirubin/albumin, incubated, and washed as in the red blood cell studies. After three washes to remove serum, mitochondria were lysed with deoxycholate and bilirubin extracted with $0.1 \mathrm{~N}$ $\mathrm{NaOH}$. Studies were done in triplicate. Results are presented as $\mu \mathrm{g}$ bilirubin per mg mitochondrial protein.

\section{RESULTS}

Mode of bilirubin uptake by erythrocytes. Erythrocytes incubated in dilute and undilute albumin-bilirubin solutions were exposed to essentially identical unbound bilirubin concentrations, but different albumin and total bilirubin levels (Table 1). The red cell bilirubin concentration was not affected by dilution of bilirubin-albumin, indicating that erythrocyte binding of bilirubin is mediated by the free bilirubin concentration and not determined by the albumin or total bilirubin level.

Stoichiometry and reversibility of bilirubin-erythrocyte binding. Erythrocytes were incubated with bilirubin-albumin solutions, pH 7.4, containing initial molar ratios in the range of $0.2-1.3$. In an infant with $3 \mathrm{~g} / \mathrm{dl}$ albumin, these conditions would be equivalent to serum bilirubin levels ranging about $5-34 \mathrm{mg} / \mathrm{dl}$ $(4.6-29 \mathrm{mg} / \mathrm{dl}$ after equilibrium). Red blood cell uptake of bilirubin throughout this range increased in proportion to the equilibrium free bilirubin concentration (Fig. 1). Saturation of erythrocyte binding was not observed. The slight deviation from linearity between uptake and unbound bilirubin concentration was a consistent observation, suggesting facilitated binding, e.g. formation of bilirubin dimers in membranes. Alternatively, it could simply reflect errors in the estimation of free bilirubin or inefficiency of bilirubin extraction at lower free bilirubin levels.

In these experiments, bilirubin was extracted from cells with nonicteric albumin. Thus, the free bilirubin concentration in the extract solution was usually very low and less than the proposed solubility limit of bilirubin at pH 7.4 (6). The experiments therefore could not differentiate whether bilirubin-membrane binding represented a reversible complex or an aggregated bili-

Table 1. Effect of serum dilution of erythrocyte binding of bilirubin

\begin{tabular}{cccc}
\hline Albumin $(\mathrm{g} / \mathrm{dl})$ & $\begin{array}{c}\text { Total bilirubin } \\
(\mathrm{mg} / \mathrm{dl})\end{array}$ & $\begin{array}{c}\text { Apparent unbound } \\
\text { bilirubin } \\
(\mathrm{nmol} / \mathrm{liter})\end{array}$ & $\begin{array}{c}\text { Red blood } \\
\text { cell bilirubin } \\
\left(\mathrm{nmol} / 10^{10} \text { cells }\right)\end{array}$ \\
\hline 2 & 14 & 48 & 14.3 \\
0.2 & 1.4 & 48 & 14.3 \\
2 & 9 & 18 & 4.8 \\
0.2 & 0.9 & 17 & 4.6 \\
\hline
\end{tabular}

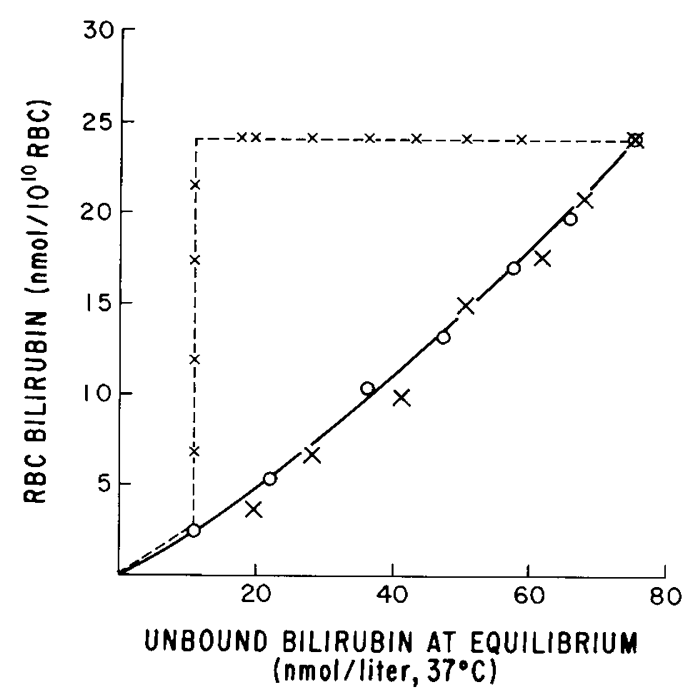

Fig. 1. $O$, erythrocytes incubated with varying molar ratios of bilirubin/albumin (0.4-1.3) pH 7.4. X, erythrocytes preloaded with bilirubin before incubation (reverse titration). --x--, expected bilirubin content of preloaded erythrocytes if tissue bilirubin represents precipitated bilirubin acid assuming solubility $7 \mathrm{nmol} /$ liter (Ref. 6). 
rubin acid-phospholipid complex as previously proposed $(6,7)$. If tissue binding involves aggregation of the bilirubin acid in membranes, those aggregates would be extracted only when the environmental free bilirubin concentration permitted resolubilization. To examine whether bilirubin aggregation is contributory to membrane binding of bilirubin under clinically observed free bilirubin levels, erythrocytes were preloaded with bilirubin by incubation with bilirubin/albumin molar ratio 1.3 and then reequilibrated with varying bilirubin/albumin solutions. This "reverse" titration was identical to the initial loading titration (Fig. 1). No hysteresis was apparent even at very high free bilirubin levels. These results indicated that erythrocyte binding of bilirubin is reversible, that insoluble bilirubin acid-phospholipid complexes do not play a significant role in bilirubin uptake by tissue under the conditions studies, and that a true equilibrium exists wherein albumin and tissue compete for binding the bilirubin pool.

Effect of $p H$ on bilirubin binding erythrocytes and mitochondria. Bilirubin has two propionic acid groups. Accepting published pK estimates of 4.3-5.3 $(19,20)$ approximately $99 \%$ of bilirubin in solution at $\mathrm{pH} 7.4$ would exist as the dianon. Relative changes in concentration of $\mathrm{BH}^{-}$and $\mathrm{BH}_{2}$ within the physiologic $\mathrm{pH}$ range would vary in proportion to the hydrogen ion concentration and square of the hydrogen ion concentration, respectively. Assuming that the $\mathrm{pK}$ of bilirubin in the bilirubinmembrane complex is not significantly altered, the binding of bilirubin to membranes at a given free bilirubin exposure would be expected to vary in proportion to the hydrogen ion concentration or square of the hydrogen ion concentration depending on whether the acid salt or bilirubin acid is the dominant driving force for tissue binding. When equilibrated with a constant free bilirubin level, red cell uptake of bilirubin was linear with hydrogen concentration (Fig. 2). Studies using mitochondria produced similar results (Fig. 3), indicating that the phenomenon is not unique to erythrocytes and probably represents a fundamental behavior of bilirubin-membrane interaction. These results would be expected if the unbound monovalent bilirubin acid salt was responsible for tissue binding. With both tissues, the ordinate intercept was slightly more than zero, indicating that a small amount of non-pH-dependent binding also occurs. This probably represents membrane complexes with the dominant bilirubin dianion.

\section{DISCUSSION}

These studies support the basic assumptions of the "free bilirubin theory"; namely, that 1) unbound bilirubin is the mediator of tissue as well as albumin binding of bilirubin, and 2) both tissue binding and albumin binding are reversible and stoichiometrically related to the concentration of unbound bilirubin. However, the uptake of bilirubin by erythrocytes and mitochondria also depends on $\mathrm{pH}$.

This study identified a linear relationship between hydrogen ion concentration and tissue binding of bilirubin, interpreted as membrane binding of the bilirubin acid salt. This conclusion is based on the premise that both $\mathrm{pK}_{1}$ and $\mathrm{pK}_{2}$ are acidic, so that within the physiologic $\mathrm{pH}$ range proton exchanges primarily involve the second carboxylic acid group. But is this assumption correct? Recent preliminary studies $(21,22)$ indicate that octanol/water and chloroform/water partitioning of bilirubin are also controlled by a single proton exchange. Reactions satisfying this requirement include:

$$
\begin{gathered}
\mathrm{BH}_{2}\left(\mathrm{CHCl}_{3}\right) \rightleftharpoons \mathrm{BH}_{2}\left(\mathrm{H}_{2} \mathrm{O}\right) \rightleftharpoons \mathrm{BH}^{-}\left(\mathrm{H}_{2} \mathrm{O}\right) \\
\mathrm{BH}^{-}\left(\mathrm{CHCl}_{3}\right) \rightleftharpoons \mathrm{BH}^{-}\left(\mathrm{H}_{2} \mathrm{O}\right) \rightleftharpoons \mathrm{B}^{-}\left(\mathrm{H}_{2} \mathrm{O}\right)
\end{gathered}
$$

Both models create chemical dilemmas. Hahm et al. (22) ascribed the observation to dissociation of the bilirubin acid (reaction a), which is incompatible with the premise of the current experiment. They found no evidence for the existence of the bilirubin dianion below $\mathrm{pH} 8.5$, and calculated a $\mathrm{pK}_{1} 7.2$ for the dissocia-

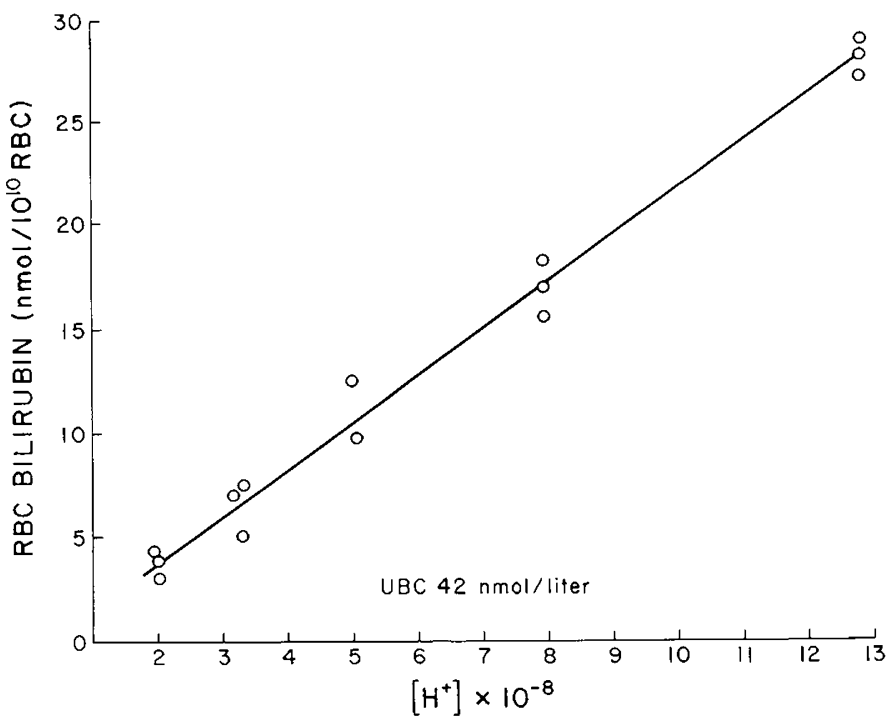

Fig. 2. Effect of hydrogen ion concentration on erythrocyte uptake of bilirubin. Cells were incubated with a constant bilirubin/albumin molar ratio at varying $\mathrm{pH}$. Each point represents a single determination.

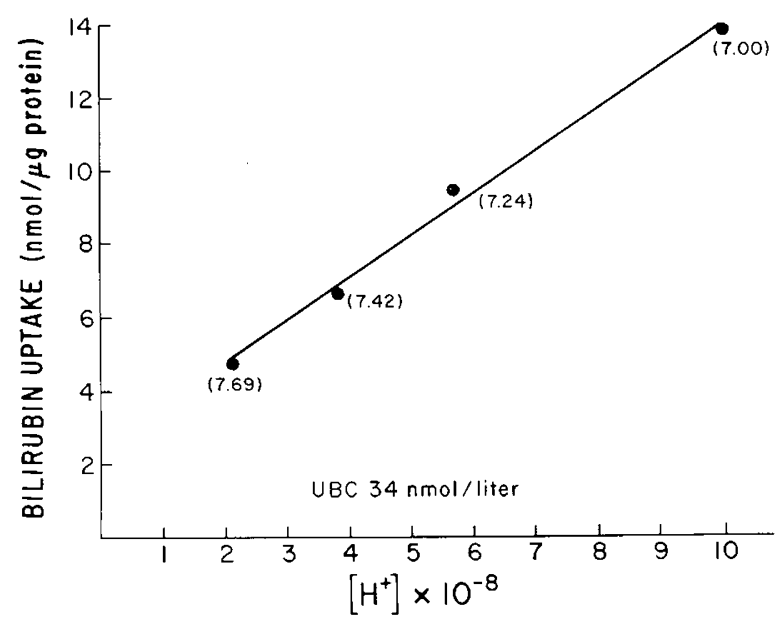

Fig. 3. Effect of hydrogen ion concentration on rat liver mitochondria uptake of bilirubin. Mitochondria were incubated with a constant bilirubin/albumin molar ratio at varying $\mathrm{pH}$. Each point represents the mean of three determinations; $\mathrm{pH}$ is indicated in parentheses.

tion of $\mathrm{BH}_{2}$ in water. Our data would fit this model only if the value $\mathrm{pK}_{2}$ were about 6.5 or lower because a higher $\mathrm{pK}$ would result in a nonlinear relationship between hydrogen ion and $\mathrm{BH}_{2}$ concentrations. The model would also require the $\mathrm{pK}$ for the remaining propionic acid to be $>8.5$ whereas the intrinsic $\mathrm{pK}$ of priopionic acid is about 4.9. Such a large shift in carboxylic acid pK would be very unusual, requiring special environmental conditions. The folded configuration of bilirubin might facilitate a basic shift in $\mathrm{pK}$, but hydrogen bonding of a carbonyl oxygen (doubly bonded in the case of bilirubin) normally decreases the pK of a carboxylic acid (23). Finally, the model must be reconciled with published potentiometric titrations of aqueous bilirubin solutions that demonstrate the addition of two, not one, protons per molecule between $\mathrm{pH} 7.8(24,25)$. The nearly simultaneous consumption of two protons, yielding an apparent $\mathrm{pK}$ of about 7.55 (25), together with a very steep titration curve were explained by Overbeek et al. (24) as precipitation of the nearly insoluble bilirubin acid and a rapid depletion of the bilirubin dianion that must maintain equilibrium with the soluble acid fraction. Thus, the true $\mathrm{pK}_{1}$ of the carboxyl groups appears to be much lower than 7.2. Although the $\mathrm{pK}$ of bilirubin acids have been estimated to be between 4.3-5.3, exact values of 
the two carboxylic acid dissociation constants remain uncertain because published studies required formamide or DMSO to solubilize bilirubin at low $\mathrm{pH}(19,20)$.

The alternative model (reaction $\mathrm{b}$ ) creates the obvious problem of how to partition a charged molecule into an organic solvent. This chemical slight-of-hand can be explained by a closer look at the surface chemistry of the water-chloroform interface, where

$$
\begin{aligned}
& \mathrm{BH}_{2\left(\mathrm{CHCl}_{2}\right)} \rightarrow \mathrm{BH}_{2 \text { (surface) }} \\
& \mathrm{BH}_{2 \text { (surface) }} \stackrel{\mathrm{BH}^{-}}{{ }_{\text {(surface) }}} \rightarrow \mathrm{BH}^{-}{ }_{\left(\mathrm{H}_{2} \mathrm{O}\right)}
\end{aligned}
$$

The conformation of the bilirubin acid salt is probably folded about the central methylene bridge, forming a hydrophobic exterior with internal hydrogen bonding of the propionic acid side chains $(26,27)$. In the folded, largely hydrophobic conformation, the acid salt would have a single ionized carboxyl group at one pole, resembling a detergent. Thus, it might readily interact with chloroform at the interface, with the hydrophobic portion buried in the chloroform and the ionized carboxylic acid group in the aqueous medium. Because of the relatively higher affinity of the nonpolar bilirubin for chloroform, the effective concentration of $\mathrm{BH}^{-}$in the chloroform (or cell membrane) interface is much higher than in aqueous solution, driving the reaction to further protonization and, in the case of chloroform, internalization of the bilirubin acid. The net reaction, however, is controlled by transformation of the water soluble bilirubin dianion into the detergent-like acid salt, described by $\mathrm{pK}_{2}$. Data obtained in chloroform/water partition studies (22) are consistent with this model by assigning values $\mathrm{pK}_{1} 4.0-5.2, \mathrm{pK}_{2} 6.5-6.9$, and $\mathrm{pK}_{\mathrm{i}} 5.1-5.4\left(\mathrm{pK}_{1}\right.$ at the interface). Using an interface $\mathrm{pK}_{1}$ of 5.2 and aqueous $\mathrm{pH} 7.0$, more than $98 \%$ of bilirubin at the chloroform-water interface would be in the form of the monovalent anion.

This model solves the paradox of partitioning a dicarboxylic acid between buffered aqueous and organic solvents with the apparent exchange of only one proton. It eliminates the need of rationalizing $\mathrm{pK}_{2}$ in reaction a), and it supports the initial premise of acidic values of $\mathrm{pK}_{1}$ and $\mathrm{pK}_{2}$. In biologic systems, the distribution of bilirubin between albumin and tissue would thus be governed principally by the following reactions:

$$
\begin{gathered}
\mathrm{AB}^{=} \rightarrow \mathrm{A}+\mathrm{B}^{-} \\
\mathrm{B}^{-=}+\mathrm{H}^{+} \rightarrow \mathrm{BH}^{-} \\
\mathrm{BH}^{-}+\mathrm{C} \rightarrow \mathrm{CBH}^{=}
\end{gathered}
$$

where $\mathrm{A}=$ albumin, $\mathrm{B}^{=}=$bilirubin dianion, and $\mathrm{C}=$ cellular membranes. Assuming accessibility of bilirubin to competing binding receptors within the body, the distribution of bilirubin would depend principally on the relative concentrations of albumin and tissue receptors, their respective binding affinities, and hydrogen ion concentration at the cell surface.

Can this model be reconciled with other interpretations of membrane-bilirubin and phospholipid-bilirubin complexes? The effects of $\mathrm{pH}$ on the binding and/or toxicity of bilirubin to tissue have previously been studied using cerebellar tissue culture (28), mitochondria (14), L-929 cells (12), erythrocytes (13), and erythrocyte ghosts $(7,8)$. All studies demonstrated increased tissue binding of bilirubin at low $\mathrm{pH}$, with or without the presence of albumin. Proposed mechanisms for increased uptake vary from altered albumin binding $(13,14)$ to precipitation of bilirubin acid in membranes $(6,7)$. The importance of the bilirubin acid salt in tissue uptake has not been previously recognized.

Brodersen and coworkers $(3,16,29)$ proposed that tissue uptake involves aggregation of $\mathrm{BH}_{2}$ in membranes, and that the risk for kernicterus could be determined as the potential for bilirubin acid aggregation, i.e. by measuring serum binding (or unbound bilirubin) and $\mathrm{pH}$. This proposal was based on observations (6) that the solubility of bilirubin in aqueous buffers (ability to dissolve crystalline bilirubin in buffer) was only about $7 \mathrm{nM}$ at $\mathrm{pH} 7.4,37^{\circ} \mathrm{C}$. Solubility increased at higher $\mathrm{pH}$ approximately in inverse proportion with the squared hydrogen ion concentration. In saturated solutions, bilirubin aggregation was greatly enhanced by addition on a phosphatidyl choline suspension, forming aggregated bilirubin-lipid complexes. Brodersen and coworkers proposed that when the unbound bilirubin level exceeds $7 \mathrm{nM}$, as it frequently does in icteric serum, it would tend to form aggregates in tissue. Bilirubin could move out of tissue only when the environment permitted dissolution of the aggregates. The deposition of bilirubin in liposomes or red cell membranes appeared to first involve phospholipid complexes with the dianion followed by protonization of the bilirubin and aggregation of bilirubin acid within the liposome or membrane (7). This sequence of events occurs within minutes at physiologic $\mathrm{pH}$.

Our data, using bilirubin/albumin ratios that reflect conditions in severely jaundiced infants, do not support these observations or conclusions. Uptake was not proportional to the squared hydrogen ion concentration, and membrane binding was reversible even at high unbound bilirubin levels. Our differences may be explained by the observation that bilirubin freshly precipitated by acidification of an aqueous solution may be 60 times more soluble (easier to redissolve at higher $\mathrm{pH}$ ) than stored crystalline bilirubin (7). Unbound bilirubin concentrations achieved herein, even at very high bilirubin/albumin ratios, probably remained within this range of solubility, whereas bilirubin solutions used in the liposome studies were 10-100 times more concentrated. While not precluding slower reactions resulting in the formation of aggregated bilirubin acid-phospholipid complexes, our data suggest that bilirubin uptake is, in the short term reversible and driven by the concentration of unbound bilirubin acid salt $\left(\mathrm{BH}^{-}\right)$.

Tipping et al. (30) studied the binding of bilirubin by phosphatidylcholine liposomes through the $\mathrm{pH}$ range of approximately 6.8-9.5 using albumin-free bilirubin solutions. Binding increased markedly from $\mathrm{pH} 9.5$ to about $\mathrm{pH} 7.7$ and then increased less rapidly as the $\mathrm{pH}$ decreased further, probably due to instability of the bilirubin solution $(10 \mu \mathrm{mol} / \mathrm{liter})$ at lower $\mathrm{pH}$. Although the authors interpreted their results to represent the formation of colloid in the liposomes, the increase in bilirubin binding from $\mathrm{pH} 8.5$ to 7.7 was essentially linear with hydrogen concentration, with a small residual non-pH-dependent bound fraction. Thus, in the $\mathrm{pH}$ range where bilirubin remained in solution, the observations of Tipping et al. (30), using liposomes, are almost identical to our findings using erythrocytes and mitochondria. Herein, however, albumin was used as a "reservoir" for bilirubin. This permitted evaluation of uptake within the physiologic $\mathrm{pH}$ range where, at equilibrium, considerable cell binding occurs even at very low free bilirubin levels.

Sato and Kashiwamata (8) examined the interaction of bilirubin with isolated human erythrocyte membranes. Their data suggested both nonsaturable binding and saturable binding to a nonprotein receptor. In their experiments, red cell ghosts were exposed to concentrations of free bilirubin ranging 0.1 to 100 $\mu \mathrm{mol} /$ liter, levels far higher than those used in our experiments or found in clinical situations. Erythrocyte membrane binding of bilirubin increased as the $\mathrm{pH}$ decreased, but again, experiments were complicated by bilirubin aggregation in the incubation vial at low $\mathrm{pH}$. They determined a Kd for saturable membrane binding of bilirubin of $2.3 \mu \mathrm{mol} /$ liter at $\mathrm{pH} 74$. Extrapolating their observations to our experimental conditions (much lower free bilirubin levels with molar ratios bilirubin:albumin of 1.3:1 or less), nonsaturable binding would be negligible and only $2 \%$ or less of available membrane sites would be saturated. This indicates that, under our experimental conditions mimicking clinically observed free bilirubin levels, most of the bilirubin uptake by intact red cells is internalized, forming reversible complexes within the cell.

This study would imply that hyperbilirubinemia is accompanied by a large pool of reversible tissue-bilirubin complexes, i.e. that tissue bilirubin is not in the form of insoluble bilirubin 
acid-phospholipid complexes. The presence of a large miscible pool is supported by the kinetics of exchange transfusion where large amounts of bilirubin are mobilized from tissue even while the total serum bilirubin concentration remains high and free bilirubin levels exceed the proposed limits of solubility of the acid. The reversibility of bilirubin-induced changes in brainstem auditory evoked response during exchange transfusion (31) further suggests that bilirubin is not precipitated in membranes even when neurotoxic events are developing.

The effect of $\mathrm{pH}$ on bilirubin toxicity in vitro was studied quantitatively by Nelson et al. (12) using L-929 cell cultures. They observed no effect of $\mathrm{pH}$ on albumin-bilirubin binding, but found a marked effect of $\mathrm{pH}$ on killing as defined by the ability of plated cells to divide and form colonies. At $\mathrm{pH} 7.4$, the free concentration for $50 \%$ cell killing was about $0.7 \mu \mathrm{mol} / \mathrm{liter}$ compared with $0.3 \mu \mathrm{mol} / \mathrm{liter}$ at $\mathrm{pH} 7.0$. Assuming a pK of 4.8 for the carboxyl groups on bilirubin, the calculated $\mathrm{LD}_{50}$ concentrations of $\mathrm{BH}^{-}$at $\mathrm{pH} 7.4$ and 7.0 would be essentially identical, i.e. 3.5 and $3.7 \mathrm{nmol} / \mathrm{liter}$, respectively. Collectively, these experiments provide strong evidence that the bilirubin monovalent anion concentration is the determining factor for both bilirubin uptake and bilirubin toxicity. Cowger (32) has pointed out similarities between the toxic effects of bilirubin, deoxycholate, and detergents on L-929 cells. The indictment of $\mathrm{BH}^{-}$as the principle form of bilirubin in lipid complexes supports the hypothesis that bilirubin toxicity results from its surfactant properties.

Some clinical studies suggest that evaluation of free bilirubin levels or serum binding improves the identification of infants at risk for kernicterus $(33,34)$, but others reported that neither total nor free bilirubin levels discriminated kernicteric from nonkernicteric premature infants (35). Failure of free bilirubin determinations to significantly improve the predictability of kernicterus may be explained in part by inattention to the modifying effects of $\mathrm{pH}$ on plasma/tissue partitioning of the bilirubin pool where:

$$
\mathrm{BH}^{-} \propto \frac{\text { unbound bilirubin concentration }}{\text { antilog } \mathrm{pH}}
$$

Technical problems in measuring the true free bilirubin in infant sera (36) may also contribute to inaccurate assignment of risk. Of perhaps greatest importance is the fact that infants are not in vitro systems, so that equilibrium conditions achieved in these experiments are probably never seen in vivo. Thus, application of any serum test to clinical management of jaundice is complicated by many other factors operative in infants including mechanisms of bilirubin transport into brain $(37,38)$ and variable tissue response to a given bilirubin load.

Acknowledgment. The skillful assistance of L. Fraser Rasmussen is gratefully acknowledged.

\section{REFERENCES}

1. Odell GB 1959 The dissociation of bilirubin from albumin and its clinical implications. J Pediatr 55:268-279

2. Wennberg RP, Ahlfors CE, Rasmussen LF 1979 The pathochemistry of kernicterus. Early Hum Dev 3:353-372

3. Brodersen R 1979 Binding of bilirubin to albumin. Crit Rev Clin Lab Sci 11:305-399

4. Nagaoka S, Cowger ML 1978 Interaction of bilirubin with lipids studied by fluorescence quenching method. J Biol Chem 253:2005-2011

5. Mustafa MG, King TE 1970 Binding of bilirubin with lipid: a possible mechanism of its toxic reactions in mitochondria. J Biol Chem 245:1084-1089

6. Brodersen R 1979 Bilirubin. Solubility and interaction with albumin and phospholipid. J Biol Chem 254:2364-2369

7. Eriksen E, Danielsen H, Brodersen R 1981 Bilirubin-liposome interaction. Binding of bilirubin dianion, protonization, and aggregation of bilirubin acid. J Biol Chem 256:4269-4274

8. Sato H, Kashiwamata S 1983 Interaction of bilirubin with human erythrocyte membranes. Biochem J 210:489-496

9. Weisiger R, Gollan JL, Ockner R 1981 Receptor for bilirubin on the liver cell surface may mediate uptake of fatty acids and other albumin-bound substances. Science 211:1048-1051

10. Levine RL, Fredricks WR, Rapoport SI 1982 Entry of bilirubin into brain due to opening of the blood-brain barrier. Pediatrics 69:255-259

11. Jacobsen J, Brodersen R 1976 The effect of $\mathrm{pH}$ on albumin-bilirubin binding. Birth Defects 12:175-178

12. Nelson T, Jacobsen J, Wennberg RP 1974 Effect of $\mathrm{pH}$ on the interaction of bilirubin with albumin and tissue culture cells. Pediatr Res 8:963-967

13. Bratlid $\mathrm{D} 1972$ The effect of $\mathrm{pH}$ on bilirubin binding by human erythrocytes. Scand J Clin Lab lnvest 29:453-459

14. Odell GB 1965 Influence of $\mathrm{pH}$ on distribution of bilirubin between albumin and mitochondria. Proc Soc Exp Biol Med 120:352-354

15. Chunga FO, Lardinois R 1971 Separation by gel filtration and microdetermination of unbound bilirubin. I. In vitro albumin and acidosis effects of albumin-bilirubin binding. Acta Paediatr Scand 60:27-32

16. Ebbesen F, Brodersen R 1982 Risk of bilirubin acid precipitation in pre-term infants with respiratory distress syndrome: considerations of blood/brain bilirubin transfer equilibrium. Early Hum Dev 6:341-355

17. Jacobsen J, Wennberg RP 1974 Determination of unbound bilirubin in the serum of newborns. Clin Chem 20:783-89

18. Hogeboom GH 1955 Fractionation of cell components of animal tissues. In: Colowick SP, Kaplan ND (ed) Methods in Enzymology, Vol 1. Academic Press, New York, pp 17-22

19. Lee JJ, Daly JH, Cowger ML 1974 Bilirubin ionic equilibrium: their effects on spectra and on conformation. Res Commun Chem Pathol Pharmacol 9:763770

20. Hansen PE, Thiessen H, Brodersen R 1979 Bilirubin acidity. Titrimetric and ${ }^{13}$ C NMR studies. Acta Chem Scand B33:281-287

21. Wennberg RP, Ahlfors CE, Wieth JO 1983 Interaction of bilirubin with tissue. Clin Res 31:139A (abstr)

22. Hahm JS, Ostrow JD, Mukerjee P, Webster CC 1986 Solubility and pK'a of unconjugated bilirubin in aqueous buffer and bile salt solutions, determined by isoextraction from chloroform. Hepatology 6:1185 (abstr)

23. Horsma DA, Nash CP 1968 Solutions of $\mathrm{N}$ substituted amino acids. III. The influence of solvent on the tautomeric equilibrium. J Phys Chem 72:23512358

24. Overbeek JTG, Vink CL, Deenstra H 1955 The solubility of bilirubin. Rec Trav Chim Pays-Bas 74:81-87

25. Krasner J, Yaffe SJ 1973 The automtic titration of bilirubin. Biochem Med $7: 128-134$

26. Bonnet R, Davies JE, Hursthouse MB, Sheldrick GM 1978 The structure of bilirubin. Proc R Soc Lond [Biol] 202:249-268

27. Kaplan D, Navon G 1982 Studies of the conformation of bilirubin and its dimethyl ester in dimethyl sulphoxide solutions by nuclear magnetic resonance. Biochem J 201:605-613

28. Silberberg DH, Johnson L, Ritter L 1970 Factors influencing toxicity of bilinubin in cerebellar tissue culture. J Pediatr 77:386-396

29. Brodersen R 1980 Bilirubin transport in the newborn infant, reviewed with relation to kernicterus. J Pediatr 96:349-356

30. Tipping E, Ketterer B, Christodoulides L 1979 Interactions of small molecules with phospholipid bilayers. Biochem J 180:327-337

31. Wennberg RP, Ahlfors CE, Bickers R, McMurtry CA, Shetter JL 1982 Abnor$\mathrm{mal}$ auditory brainstem response in a newborn infant with hyperbilirubinemia. Improvement with exchange transfusion. J Pediatr 100:624-626

32. Cowger ML 1971 Mechanism of bilirubin toxicity on tissue culture cells: factors that affect toxicity, reversibility by albumin, and comparisons with other respiratory poisons and surfactants. Biochem Med 5:1-16

33. Valaes T, Kapitulnik J, Kaufmann NA 1976 Experience with Sephadex gel filtration in assessing the risk of bilirubin encephalopathy in neonatal jaundice. Birth Defects 12:215-228

34. Cashore WJ, Oh W 1982 Unbound bilirubin and kernicterus in low-birthweight infants. Pediatrics 69:481-485

35. Ritter DA, Kenny JD, Norton H, Rudolph AJ 1982 A prospective study of free bilirubin and other risk factors in the development of kernicterus in premature infants. Pediatrics 69:260-266

36. Ahlfors CE 1981 Effect of serum dilution on apparent unbound bilirubin concentrations measured by the peroxidase method. Clin Chem 27:692-696

37. Pardridge WM 1981 Transport of protein-bound hormones into tissues in vivo. Endocrine Rev 2;103-123

38. Robinson PJ, Rapoport SI 1986 Kinetics of protein binding determine rates of uptake of drugs by brain. Am J Physiol 251:R1212-R1220 